\title{
Symptomatic talar beak in talocalcaneal coalition
}

\author{
Selahattin Ozyurek, ${ }^{1}$ Ferhat Guler, ${ }^{2}$ Adil Turan, ${ }^{2}$ Ozkan Kose ${ }^{2}$
}

${ }^{1}$ Department of Orthopaedics and Traumatology, Aksaz Military Hospital, Mugla,

Turkey

${ }^{2}$ Department of Orthopaedics and Traumatology, Antalya Training and Research Hospital, Antalya, Turkey

\section{Correspondence to} Dr Selahattin Ozyurek, fsozyurek@yahoo.com

\begin{tabular}{l}
\hline To cite: Ozyurek S, Guler $\mathrm{F}$, \\
Turan A, et al. BMJ Case \\
Rep Published online: \\
[please include Day Month \\
Year] doi:10.1136/bcr-2013- \\
009309 \\
\hline
\end{tabular}

\section{DESCRIPTION}

A 16-year-old boy presented to our outpatient clinic with the complaint of right-sided anterior ankle pain for 6 months. The complaints were worse with prolonged physical activity, particularly after running and jumping. There was no history of antecedent trauma or injury to his ankle. His medical history was unremarkable. Physical examination revealed flatfoot deformity, tenderness over the anterior aspect of his ankle at the level of talonavicular joint, and there was a palpable firm mass at the same localisation. The complaints were worse with dorsiflexion of the ankle and the patient could not squat. The neurovascular examination was normal. The range of tibiotalar joint movements was within normal limits; however, subtalar joint movements were restricted.

Plain radiographs of the right foot showed continuous $\mathrm{C}$ sign and a prominent talar beak which was consistent with tarsal coalition (figure 1). Further evaluation with CT clearly demonstrated the talocalcaneal coalition of the middle subtalar facet (figure 2). Initially, the patient was treated with activity modification, rest and analgesics for 6 weeks. However, the patient did not respond to conservative treatment. MRI was performed to delineate other possible causes of persistant anterior ankle pain. Sagittal T12-weighted MRI of the ankle demonstrated bone marrow oedema within the talar neck and bursa formation over the talar beak (figure 3). Talar beak and bursa were removed with open surgery.

Tarsal coalition is an abnormal bony, cartilaginous or fibrous union between two or more tarsal bones and is an overlooked cause of foot and ankle pain. ${ }^{1}$ Talocalcaneal and calcaneonavicular coalitions are the most common forms of tarsal coalition, representing at least $90 \%$ of all cases. ${ }^{1}$

The term 'talar beak' refers to a flaring of the superior aspect of the talar head, seen on lateral

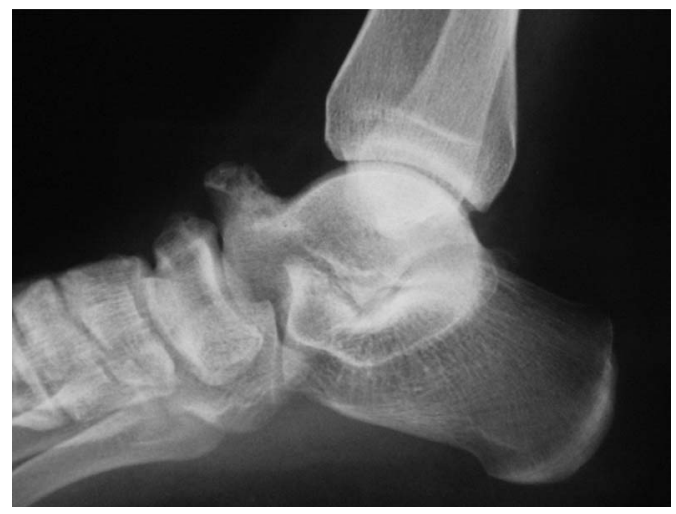

Figure 1 Plain radiographs of the right foot showed continuous $\mathrm{C}$ sign and a prominent talar beak.

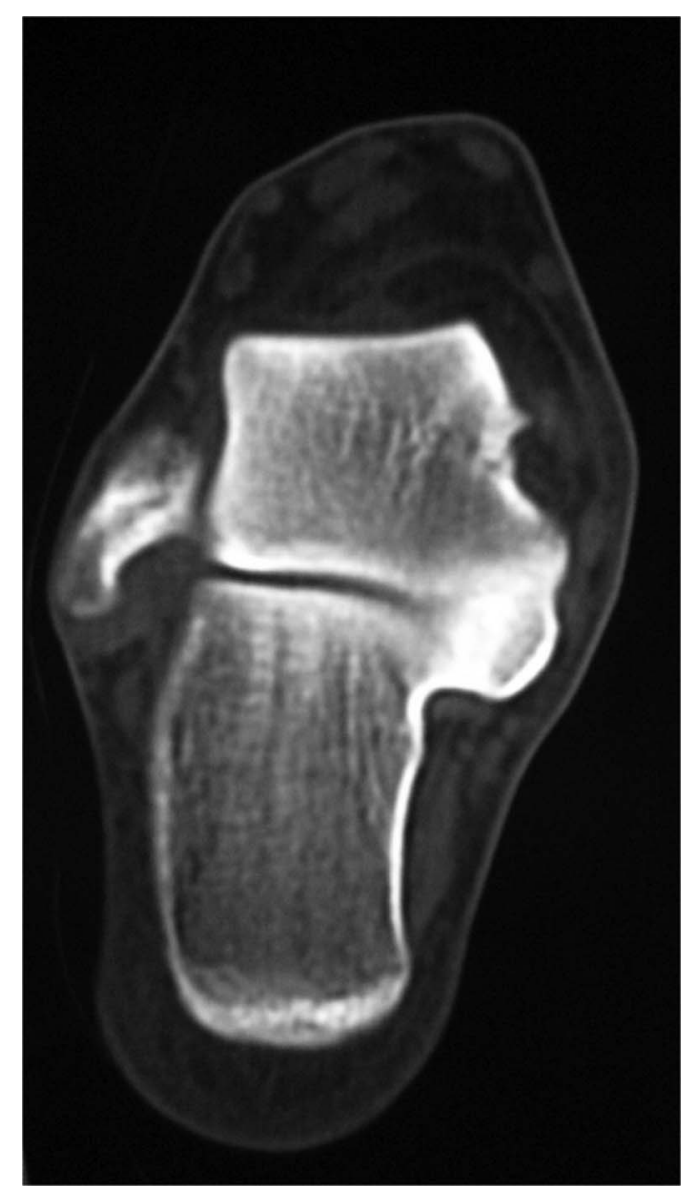

Figure 2 CT demonstrated talo-calcaneal coalition of the middle subtalar facet.

radiographs. $^{2}$ This is an indirect sign of talocalcaneal coalition and thought to form as a consequence of impaired subtalar joint motion, which results in the navicular overriding the talus. ${ }^{2} 3$

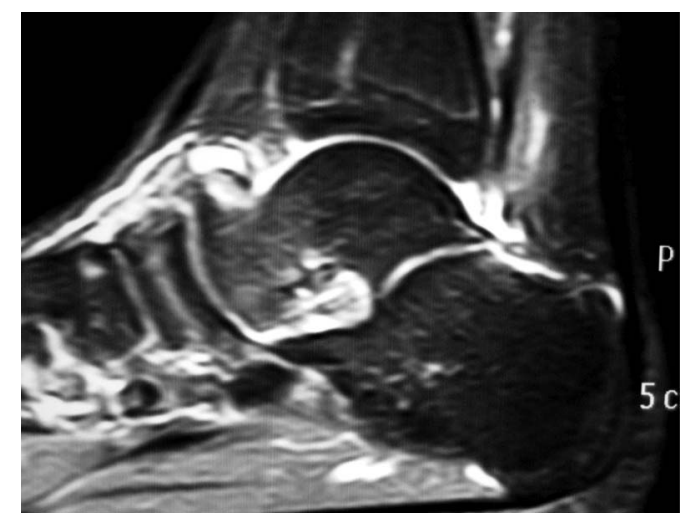

Figure 3 Sagittal T12-weighted MRI of the ankle demonstrated bone marrow oedema within the talar neck and bursa formation over the talar beak. 


\section{Learning points}

- Talonavicular tarsal coalition is often overlooked term for foot pain and deformity that can be identified on a lateral radiograph of the foot or ankle on the basis of the presence of the talar beak.

- Multiplanar CT imaging and MRI are diagnostic modalities of choice in tarsal coalition.
Competing interests None.

Patient consent Obtained.

Provenance and peer review Not commissioned; externally peer reviewed.

\section{REFERENCES}

1 Schenkel D, deGraauw J, deGraauw C. Talocalcaneal coalition in a 15-year-old female basketball player. J Can Chiropr Assoc 2010;54:222-8.

2 Newman IS, Newberg AH. Congenital tarsal coalition: multimodality evaluation with emphasis on CT and MR Imaging. Radiographics 2000;20:321-32.

3 Varich L, Bancroft L. Radiologic case study. Talocalcaneal coalition. Orthopedics 2010;33:374-452.

Contributors All authors have contributed equally to the article. All authors were involved in concept, design, writing and reviewing the article and all authors approved the final draft of the manuscript.

Copyright 2013 BMJ Publishing Group. All rights reserved. For permission to reuse any of this content visit http://group.bmj.com/group/rights-licensing/permissions.

BMJ Case Report Fellows may re-use this article for personal use and teaching without any further permission.

Become a Fellow of BMJ Case Reports today and you can:

- Submit as many cases as you like

- Enjoy fast sympathetic peer review and rapid publication of accepted articles

- Access all the published articles

- Re-use any of the published material for personal use and teaching without further permission

For information on Institutional Fellowships contact consortiasales@bmjgroup.com

Visit casereports.bmj.com for more articles like this and to become a Fellow 